\begin{tabular}{|l|l|l||}
\hline \multicolumn{2}{|c|}{ PublisherInfo } \\
\hline \hline PublisherName & $:$ & BioMed Central \\
\hline \hline PublisherLocation & $:$ & London \\
\hline \hline PublisherImprintName & $:$ & BioMed Central \\
\hline \hline
\end{tabular}

\title{
De-differentiation in vitro
}

\begin{tabular}{|l|l|l||}
\hline \multicolumn{2}{|c|}{ ArticleInfo } \\
\hline \hline ArticleID & $:$ & 3788 \\
\hline \hline ArticleDOI & $:$ & $10.1186 /$ gb-spotlight-20001005-03 \\
\hline \hline ArticleCitationID & $:$ & spotlight-20001005-03 \\
\hline \hline ArticleSequenceNumber & $:$ & 225 \\
\hline \hline ArticleCategory & $:$ & Research news \\
\hline \hline ArticleFirstPage & $:$ & 1 \\
\hline \hline ArticleLastPage & $:$ & 2 \\
\hline \hline & $:$ & RegistrationDate : 2000-10-05 \\
ArticleHistory & $:$ & OnlineDate $\quad 2000-10-05$ \\
\hline \hline ArticleCopyright & $:$ & BioMed Central Ltd2000 \\
\hline \hline ArticleGrants & $:$ & \\
\hline \hline ArticleContext & $:$ & 130591111 \\
\hline \hline
\end{tabular}


William Wells

Email: wells@biotext.com

Cloning works because even highly differentiated somatic nuclei can de-differentiate and reacquire their ability to form all the cells of the body. The de-differentiation process is driven by egg cytoplasm, and in the 29 September Science Kikyo et al. report that the chromatin remodeling protein ISW1 is probably one component of the de-differentiation machinery (Science 2000, 289:2360-2362). Kikyo et $a l$. identify a number of proteins that are released from permeabilized frog somatic nuclei only in the presence of frog egg cytoplasm plus ATP. Fractionation of the egg cytoplasm yields ISW1, a member of the SWI2/SNF2 superfamily of chromatin remodeling proteins. Other chromatin remodeling proteins are not active in the assay, but unidentified proteins are needed in addition to ISW1. Further discoveries in this field may allow for cloning, or the derivation of stem cells, without the need to use egg cells.

\section{References}

1. Science magazine, [http://www.sciencemag.org/]

2. ISWI, a member of the SWI2/SNF2 ATPase family, encodes the $140 \mathrm{kDa}$ subunit of the nucleosome remodeling factor.

3. The future of cloning. 